\title{
Second-line afatinib administration in an elderly patient with squamous cell carcinoma
}

\author{
This article was published in the following Dove Press journal: \\ Therapeutics and Clinical Risk Management \\ 20 March 2017 \\ Number of times this article has been viewed
}

\author{
Wolfgang Hohenforst- \\ Schmidt ${ }^{\prime}$ \\ Paul Zarogoulidis ${ }^{2}$ \\ Michael Steinheimer ${ }^{1}$ \\ Naim Benhassen ${ }^{3}$ \\ Chrysanthi Sardeli ${ }^{4}$ \\ Nikos Stalikas ${ }^{2}$ \\ Melpomeni Toitou ${ }^{2}$ \\ Haidong Huang ${ }^{5}$ \\ 'Sana Clinic Group Franken, \\ Department of Cardiology/ \\ Pulmonology/Intensive Care/ \\ Nephrology, "Hof” Clinics, University \\ of Erlangen, Hof, Germany; ${ }^{2}$ Pulmonary \\ Department - Oncology Unit, \\ "G Papanikolaou" General Hospital, \\ Thessaloniki, Greece; ${ }^{3}$ Medical \\ Clinic I, "Fuerth" Hospital, University \\ of Erlangen, Fuerth, Germany; \\ ${ }^{4}$ Department of Pharmacology \& \\ Clinical Pharmacology, School of \\ Medicine, Faculty of Health Sciences, \\ Aristotle University of Thessaloniki, \\ Thessaloniki, Greece; ${ }^{5}$ Department \\ of Respiratory and Critical Care \\ Medicine, Changhai Hospital/ \\ First Affiliated Hospital of the \\ Secondary Military Medical \\ University, Shanghai, China
}

Correspondence: Paul Zarogoulidis Pulmonary Department - Oncology Unit, "G Papanikolaou" General Hospital, Aristotle University of Thessaloniki, Exohi I 100, Thessaloniki 57010, Greece Tel +306977271974

Fax +30231099 2424 Email pzarog@hotmail.com
Introduction: The majority of cases of lung cancer are still diagnosed at a late stage. At this stage, palliative therapeutic options including nonspecific cytotoxic drugs, targeted therapy, or immunotherapy can be utilized. In 2016, immunotherapy was approved in Europe for squamous cell carcinoma and adenocarcinoma. Moreover, afatinib was also approved as second-line therapy for squamous cell carcinoma.

Case report: This article presents a case of a 76-year-old male with squamous cell carcinoma who received nab-paclitaxel as first-line therapy, and his treatment was switched to the tyrosine kinase inhibitor afatinib (40 mg) after disease progression with left lung atelectasis. After receiving afatinib for only 28 days, the atelectasis resolved. No adverse effects were observed from the afatinib therapy.

Discussion: In this case, afatinib $40 \mathrm{mg}$ proved to be an effective alternative treatment for an elderly patient. Treatment choice should be based on the performance status of the patient, cost-effectiveness, and drug treatment guidelines.

Keywords: lung cancer, EGFR, afatinib

\section{Introduction}

Lung cancer is most commonly diagnosed at a late stage because of the lack of early symptoms and no reliable screening markers. However, early detection is very important; hence, several authors have proposed specific target groups and techniques for lung cancer screening. ${ }^{1,2}$ Treatment for stage IV disease could be divided in four groups: 1) nonspecific cytotoxic agents, 2) tyrosine kinase inhibitors (TKIs), 3) immunotherapy, and 4) local therapy (eg, endoscopic debulking techniques, microwave, or radiofrequency). ${ }^{3-6}$ Nonspecific cytotoxic agents have a limitation because of the drugrelated complications in the elderly and those with a compromised performance status. Therapies that target epidermal growth factor receptor (EGFR) and anaplastic lymphoma kinase are currently available. In order to identify these mutations, rebiopsy if indicated or liquid biopsy may be needed to identify a possible mutation. ${ }^{7-13}$ Immunotherapy was approved in Europe for both squamous cell carcinoma and adenocarcinoma. ${ }^{14}$ Immunotherapy utilized as maintenance therapy is actively being investigated. ${ }^{15}$ The novel immunotherapy pembrolizumab has been approved as first-line treatment for non-small cell lung cancer (NSCLC) based on the expression of anti-PD-1/PD-L1 antibodies. ${ }^{16}$ The major issue with immunotherapy is the cost; however, since immunotherapy is becoming a "targeted" therapy, it will certainly become a first choice of treatment for lung cancer. TKIs still remain the targeted therapy of choice where possible with novel agents being already on the market such as AZD9291 osimertinib. Further experimentation with TKIs has identified new treatment options such 


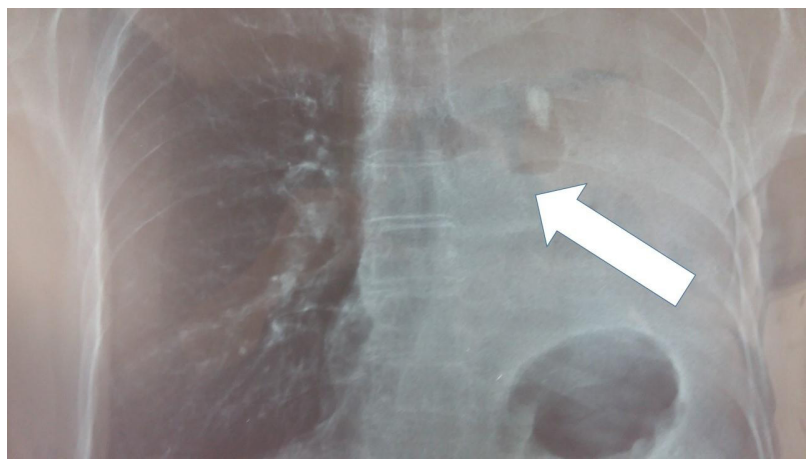

Figure I Left lung atelectasis (during abraxane, last therapy session); white arrow indicates the central mass to the left main bronchus.

Giotrif $^{\circledR}$ (afatinib), which is approved for second-line treatment without the patient expressing an EGFR mutation. ${ }^{17,18}$ Afatinib is a second-generation protein kinase inhibitor that irreversibly inhibits EGFR. ${ }^{19}$

\section{Case report}

A 76-year-old male was diagnosed with squamous cell carcinoma from a central mass in the left stem bronchus. The patient had 150 pack-years of tobacco abuse and no distant metastasis, but he could not undergo surgery because of the location of the central mass. He was offered and agreed to receive nab-paclitaxel as first-line treatment because of his age and performance status. After four cycles of therapy, atelectasis was observed consistent with disease progression on chest imaging and afatinib $40 \mathrm{mg}$ was suggested to the patient, which he agreed upon and initiated. The patient performance status was Eastern Cooperative Oncology Group (ECOG) 0 upon initiation of afatinib $40 \mathrm{mg}$. The EGFR status was negative. No adverse effects were observed from the administration of nab-paclitaxel, nor afatinib $40 \mathrm{mg}$ till

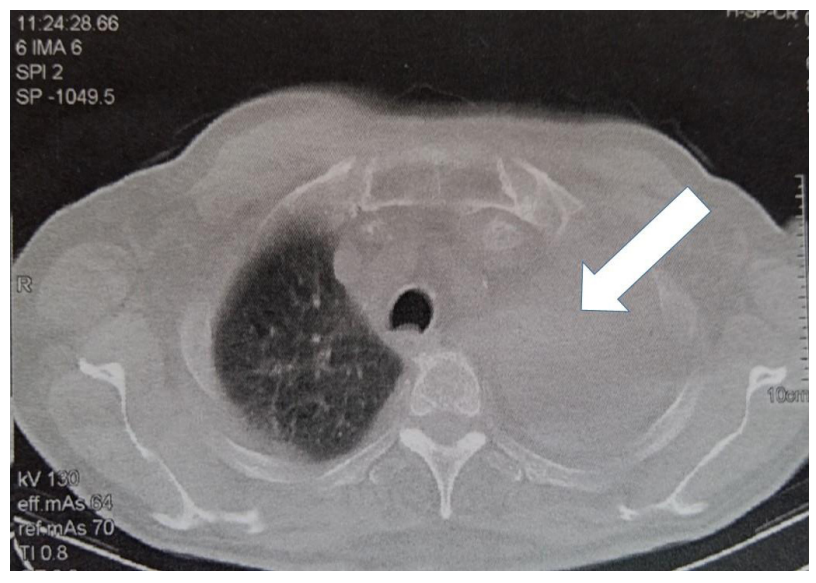

Figure 2 Computed tomography scan of the thorax (during abraxane); the left lung is totally collapsed (white arrow).

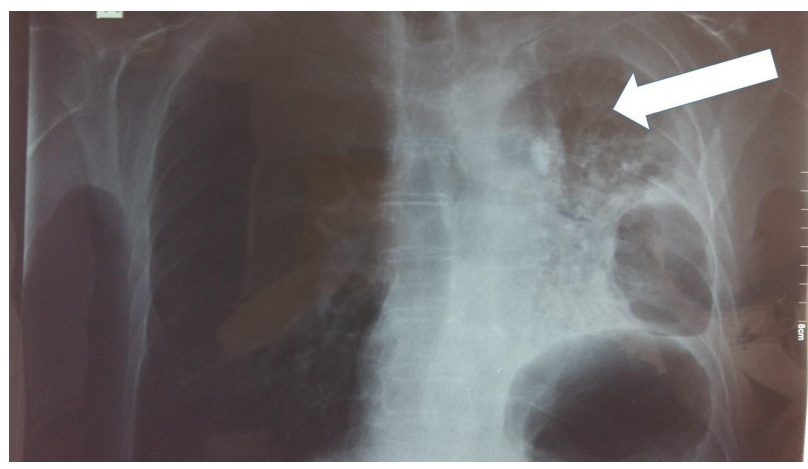

Figure 3 After 28 days under afatinib $40 \mathrm{mg}$ (the mass has started to shrink and the left lung to inflate, white arrow).

date. After only 28 days of the afatinib $40 \mathrm{mg}$ administration, a complete resolution of the atelectasis of the left lung was observed consistent with drug response (Figures 1-4). A written informed consent statement was obtained from the patient to have the case details and any accompanying images published by the authors.

\section{Discussion}

There are several nonspecific cytotoxic agents that a treating physician can offer for squamous cell lung cancer. ${ }^{4}$ It is known that these drugs are given based on the performance status and age of the patient. Adverse effects are severe in several patients, and hospitalization is also necessary if these occur. ${ }^{20,21}$ In a recent study, it was proposed that a single agent or avoidance of platinum analogs for the elderly aged $\geq 70$ years could be a solution. ${ }^{21}$ On the basis of the center experience and the patient characteristics, a single agent (nab-paclitaxel $150 \mathrm{mg}$ ) was chosen to be administered weekly on days 1,8 , and 15 with 2 weeks off based on the current institutional treatment algorithms. The patient did not have any adverse effects; however, there was radiographic

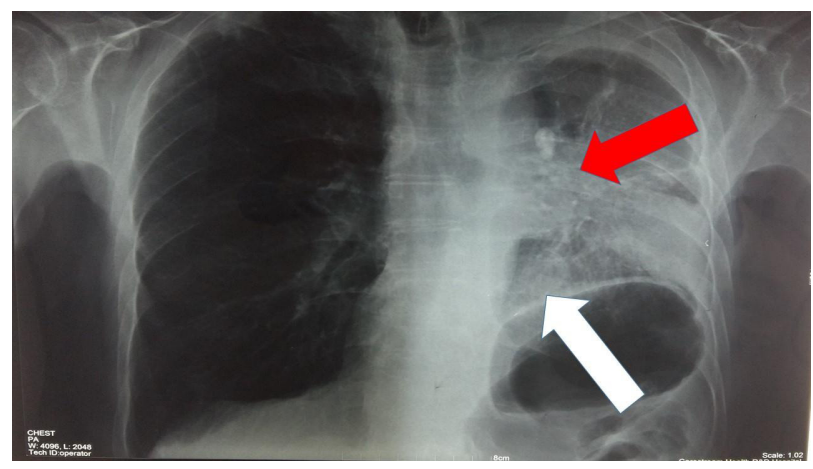

Figure 4 After 65 days from the afatinib $40 \mathrm{mg}$ administration (white arrow indicates the part of the left lower lobe that has been inflated and red arrow indicates the central mass that used to totally block the left lung). 
evidence of disease progression for which afatinib $40 \mathrm{mg}$ was chosen to be administered. In this case, the patient had a remarkable response with only 28 days of administration. Of note, in a recent study, the overexpression of secreted protein acidic and rich in cysteine (SPARC), which binds to albumin, was used as marker of treatment efficiency with afatinib. ${ }^{22}$ The patient did not have any adverse effects from the afatinib $40 \mathrm{mg}$ administration. Immunotherapy is another potential choice that treating physicians could consider in elderly patients, since adverse effects are less frequent. Further studies are needed to determine efficacy and safety profiles in this patient population.

\section{Acknowledgment}

The authors would like to thank Dr Mina Gaga for the useful insights in the presentation of the case.

\section{Disclosure}

Paul Zarogoulidis is a member of the advisory board of Boehringer Ingelheim ${ }^{\circledR}$ Greece for Oncology agents. The authors report no other conflicts of interest in this work.

\section{References}

1. Kanodra NM, Pope C, Halbert CH, Silvestri GA, Rice LJ, Tanner NT. Primary care provider and patient perspectives on lung cancer screening. A qualitative study. Ann Am Thorac Soc. 2016;13(11):1977-1982.

2. Henschke CI, Yip R, Smith JP, et al. CT screening for lung cancer: partsolid nodules in baseline and annual repeat rounds. AJR Am J Roentgenol. 2016;207(6):1176-1184.

3. Domvri K, Zarogoulidis P, Darwiche K, et al. Molecular targeted drugs and biomarkers in NSCLC, the evolving role of individualized therapy. J Cancer. 2013;4(9):736-754.

4. Zarogoulidis K, Zarogoulidis P, Darwiche K, et al. Treatment of non-small cell lung cancer (NSCLC). J Thorac Dis. 2013;5(Suppl 4): S389-S396.

5. Stratakos G, Gerovasili V, Dimitropoulos C, et al. Survival and quality of life benefit after endoscopic management of malignant central airway obstruction. J Cancer. 2016;7(7):794-802.

6. Hohenforst-Schmidt W, Zarogoulidis P, Pitsiou G, et al. Drug eluting stents for malignant airway obstruction: a critical review of the literature. J Cancer. 2016;7(4):377-390.

7. Zarogoulidis P, Gaga M, Huang H, Darwiche K, Rapti A, Hohenforst-Schmidt W. Tissue is the issue and tissue competition. Re-biopsy for mutation T790: where and why? Clin Transl Med. 2017; 6(1):6.
8. Papadopoulou E, Tsoulos N, Tsirigoti A, et al. Determination of EGFR and KRAS mutational status in Greek non-small-cell lung cancer patients. Oncol Lett. 2015;10(4):217-2184.

9. Zaric B, Stojsic V, Kovacevic T, et al. Clinical characteristics, tumor, node, metastasis status, and mutation rate in domain of epidermal growth factor receptor gene in Serbian patients with lung adenocarcinoma. J Thorac Oncol. 2014;9(9):1406-1410.

10. Hohenforst-Schmidt W, Zarogoulidis P, Steinheimer M, et al. Tyrosine kinase inhibitors for the elderly. J Cancer. 2016;7(6):687-693.

11. Yarmus L, Akulian J, Gilbert C, et al. Optimizing endobronchial ultrasound for molecular analysis. How many passes are needed? Ann Am Thorac Soc. 2013;10(6):636-643.

12. Soejima K, Yasuda H, Hirano T. Osimertinib for EGFR T790M mutation-positive non-small cell lung cancer. Expert Rev Clin Pharmacol. 2016;10(1):31-38.

13. Speranza G, Cohen V, Agulnik JS, et al. Molecular changes in epidermal growth factor receptor (EGFR) in non-small cell lung cancer (NSCLC) biopsies at time of progression compared to initial biopsy. J Clin Oncol. 2009;27(15 Suppl):e22066.

14. Metro G, Ricciuti B, Brambilla M, et al. The safety of nivolumab for the treatment of advanced non-small cell lung cancer. Expert Opin Drug Saf. 2016;16(1):101-109.

15. Blumenschein G Jr, Chandler J, Garon EB, et al. PS01.59: CheckMate 370: a master protocol of phase $1 / 2$ studies of nivolumab as maintenance or first-line +/- standard-of-care therapies in advanced NSCLC: Topic: Medical Oncology. J Thorac Oncol. 2016;11(11S):S307.

16. Valecha GK, Vennepureddy A, Ibrahim U, Safa F, Samra B, Atallah JP. Anti-PD-1/PD-L1 antibodies in non-small cell lung cancer: the era of immunotherapy. Expert Rev Anticancer Ther. 2017;17(1):47-59.

17. Cobo M, Gutierrez V, Rodelo L, Lopez O, Ruiz M, Godoy A. Afatinib en pacientes con carcinoma de células escamosas de pulmón: contexto actual y la opción de tratamiento oral [Afatinib in patients with squamous cell carcinoma of the lung: current context and the option of oral treatment]. Med Clin [Barc]. 2016;146 (Suppl 1):25-29. Spanish.

18. Keating GM. Afatinib: a review in advanced non-small cell lung cancer. Target Oncol. 2016;11(6):825-835.

19. Diz Tain P, Gonzalez AL, Garcia-Palomo A. Mecanismo de acción y desarrollo preclínico de afatinib [Mechanism of action and preclinical development of afatinib]. Med Clin [Barc]. 2016;146(Suppl 1):7-11. Spanish.

20. Yang J, He J, Yu M, Li T, Luo L, Liu P. The efficacy and safety of platinum plus gemcitabine (PG) chemotherapy with or without molecular targeted agent (MTA) in first-line treatment of non-small cell lung cancer (NSCLC). Medicine. 2016;95(50):e5599.

21. Santos FN, Castria TB, Cruz MR, Riera R. Chemotherapy for advanced non-small cell lung cancer in the elderly population. Sao Paulo Med J. 2016;134(5):465-466.

22. Komiya K, Nakamura T, Nakashima C, et al. SPARC is a possible predictive marker for albumin-bound paclitaxel in non-small-cell lung cancer. OncoTargets Ther. 2016;9:6663-6668.
Therapeutics and Clinical Risk Management

\section{Publish your work in this journal}

Therapeutics and Clinical Risk Management is an international, peerreviewed journal of clinical therapeutics and risk management, focusing on concise rapid reporting of clinical studies in all therapeutic areas, outcomes, safety, and programs for the effective, safe, and sustained use of medicines. This journal is indexed on PubMed Central, CAS,

\section{Dovepress}

EMBase, Scopus and the Elsevier Bibliographic databases. The manuscript management system is completely online and includes a very quick and fair peer-review system, which is all easy to use. Visit http://www.dovepress.com/testimonials.php to read real quotes from published authors. 